\title{
INTERNATIONAL TREATIES AND THE CEAUSE "REBUS SIC STANTIBUS"
}

\author{
JoHn P. Bullington
}

During the past quarter of a century the increase in complexity of international relations and the growth of economic interdependence among nations have required that states regulate their relations more and more by treaties, since customary international law has been unable to keep abreast of modern developments. Despite the continuous violation, both of treaties and of customary rules of international law, by all the contestants in the recent European war, treaties continue to be drawn and signed, and seem on all sides to be regarded as effectively binding the parties to them. The importance of treaties as a present means of establishing peaceful intercourse and mutually advantageous economic relations between states makes it worth while to reconsider the doctrine advanced and accepted by most modern writers which would, under varying circumstances, authorize the abrogation of treaties without the consent of all the contracting parties-the mere fiat of a single state being sufficient to annul freely contracted obligations. This theory is usually discussed under the heading "The Rebus Sic Stantibus Clanse."1

It is scarcely to be doubted that treaties are ordinarily consummated after a due consideration by all parties of the possible benefits which may in the future accrue to them through the operation of the treaty under consideration. It so happens that one state often finds that it has made a bad bargain, or that it failed to take into consideration future contingencies that might operate to its disadvantage. Thus the state may find itself bound either for a term of years or in perpetuity to a contract, the execution of which may entail varying degrees of injury to itself. It is just possible that the continued existence of the state as an independent political division may be threatened. On the other hand, mere hardship may flow from the execution of the treaty.

' See II STRUPP, WÖRTERBLCCH DES VÖLKERRECHTS, 336. 
Grotius and the natural law writers, influenced perhaps by the rigor of the Roman law of contracts, saw no legitimate relief for the suffering party, but would require the complete fulfillment of the terms of the treaty. ${ }^{2}$ Vattel, however, excepted those treaties which would be "pernicious" to the contracting state, or would result in a neglect of the sovereign's duty towards his citizens. ${ }^{3}$

Since Vattel's time, writers on international law have come to an almost unanimous recognition that the clause rebus sic stantibus is to be read into every treaty, though pacta sunt servanda is still retained as the rule. ${ }^{4}$ Despite this unanimity of opinion as to the existence of the clause in treaties, there is little agreement as to what it means or the effect that is to be given to it. Some authorities would severely limit the field of its application and deny any unilateral interpretation of it, while others would read into it a meaning which would result in the state being bound by the treaty only so long as it saw fit. ${ }^{6}$ The reasons for the existence of the clause are found by some to be in the nature of the state and its sovereignty, ${ }^{7}$ by others it is deduced from the fact that nations make treaties only for their own benefit $^{8}$ and by still others it is based upon the theory that certain attributes of the state, such as "freedom of internal development," "sovereignty," etc., are inalienable. ${ }^{\circ}$

'Grotius, De Jure Belit ac Pacis, Lib. II, Ch. XVI, § xxv, 2.

- Vatrer, Le Drótt des Gens, Liv. II, Ch. XII, 372, 378.

- The authorities are collected in Chapter IV of KaUfMand, Das WESEN

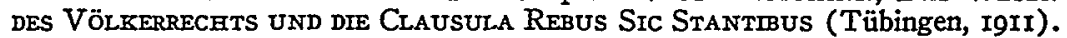

Fiore seems to be the only European writer who condemns the theory categorically and without exception. See FIORE, InTERnational LAw Codified (Borchard's Translation, 19r8) $\$ \$ 787,833,834$.

'II Pradier-Fodere, Traite de Droit International Public, 888-889; II Nys, Le DroIt INTERNATIONAI, 53I-535; I OPPENhEIM, INTERNATIONAI LAW (3d ed. 1920) 37I-372; I WESTLAKE, INTERNATIONAL LAW (2d ed. I9I0) 285; II P.HILIMORE, INTERNational LaW (3d ed. i879), i I4.

- I Mérignhac, Traite de Droit Public International, i33; II Wharton, Digest of International Law (I886) § I37a; Bluntschl, Drott INTternational Codifte, 4 e. éd., $\$ \S 458,460$; I Treitschke, Politics, 28. 104.

'Jetlinek, Die LeHRe von den StaAtenverbindungen (Wien, i882) roo-

Biuntsceli, op. cit. supra note 6, observations to $\$ 460$.

' II Rivier, Principes du Droit des Gens 128. 
Manifestly, if Treitschke's theory of the state as force ${ }^{10}$ be accepted, we are compelled to admit that the state may at any time abrogate treaties barring the expression of that force. The theory that the state cannot limit itself must also lead to the same conclusion. Here, as in so many branches of the law, the influence of the Austinian concept of "sovereignty" has worked injury to the free development of the law. Deifying the sovereignty of the state, as does Jellinek, ${ }^{11}$ for example, leads inevitably to the conclusion that treaties are mere "chiffons de papier." No less disastrous would be the results if the theories of Ullman ${ }^{12}$ and de Louter ${ }^{13}$ were accepted. To them the state can be bound only by its own will, which logically means that it cannot be bound at all. Treaties could be broken whenever it seemed expedient for the state to do so. Under such theories no necessity should be felt for implying a rebus sic stantibus clause to justify a treaty abrogation. Fortunately, experience so effectively denies such theories that there is little danger of their continued general acceptance; yet it cannot be denied that these highly metaphysical concepts of the state and sovereignty have exerted a powerful influence upon courts and legal thinkers alike. ${ }^{14}$

The more modern functional theories of the state, in denying to its government any such extraordinary powers as were postulated by Bodin and Hobbes for their sovereigns, have done much to break down the old rigid concepts and replace them with more realistic and flexible ones.

It is thus apparent that the legal nature of treaties and the possibility of legally abrogating them has not been imimune from the influence of political theory. If the notion of the supremacy of the state over law be accepted, then it is useless to discuss the

${ }^{10}$ Treitschke, Politics (I9I6) $3 \mathrm{ff}$.

" JeLIINEK, op. cit. supra note 7 , passim.

${ }^{1}$ UlLAMAN, VöLKERRECHT, 2 auf. (Tübingen, Ig08) 6.

23 De Louter, Le Droit International Public Positif (Trans. from the Dutch) (Oxford, 1920) I72 ff.

"See the exposition of these news in Borchard, Political Theory and International Law, in the volume of essays, Merriam and Barnes, Politicar THEORIES (I924) 120-I40. 
effect of treaties. The effect will be only whatever a particular state wants it to be, provided, of course, that state is physically capable of enforcing its wishes. If, on the other hand, we accept the theory that the state is bound by law, and particularly by international law, as experience impels us to do, it becomes most important to discover the legal effect of treaties. In attempting to discover the validity or non-validity of the rebus sic stantibus clause, the latter theory of the existence of some law, binding states, will be accepted.

Many states have found the theory underlying the rebus sic stantibus clause not repugnant to their particular interests, and have not hesitated to make use of it. How far this practice supports the validity of the theory must be determined by an examination of the precedents in the attempt to find their meaning. The classic example is that of Russia's note of $19 / 3$ I October, I870, notifying the other powers that she no longer considered herself bound by Articles II, I3 and I4 of the Treaty of Paris (March 3r, 1856), neutralizing the Black Sea and limiting Russia's forces there. It is noteworthy that Russia assigned as reasons for her attempted unilateral abrogation of the treaty certain alleged violations of the treaty by the other signatory powers as well as the changed conditions then existing. ${ }^{15}$ Russia's action resulted in a conference at London of the powers involved, where a new treaty was drawn acceding to Russia's demands. At the same conference a protocol was signed by all the parties, including Russia, to the effect that they recognized, as a principle of international law, that no nation could be absolved from treaty duties without the consent of all the parties, and after an amicable agreement. ${ }^{16}$ Russia acted upon the theory of the rebus sic stantibus clause, but her act was recognized as legitimate by no other state.

Few writers, however, have found this declaration made at London incompatible with their own theories of the clause. Certainly Russia found it no obstacle to a subsequent declaration that due to changed circumstances the port of Batoum would no

\footnotetext{
${ }^{15}$ KaUfManN, supra note 4 , at I2 et seq.

${ }^{16}$ De Martens, Nouveau Receutl des Traités, ie sér., t. I8, 278.
} 
longer be a free one, despite Article 59 of the Treaty of Berlin. Here again Russia was not sufficiently sure of change of circumstance alone justifying the breach of a treaty provision, and argued further that the particular article of the treaty was a mere gratuitous voeu on the part of Russia and therefore never legally binding. ${ }^{17}$ The instance was of such minor importance, however, that other nations concerned were not disposed to oppose Russia's aims, so the incident has little value as a precedent. In both cases Russia offered numerous reasons for her acts founded on the "security and dignity of the Empire" and the "peril" in which the respect of her engagements would put her. ${ }^{18}$

The Treaty of Frankfort, signed in I87I after the cessation of hostilities between France and Germany, provided that the nationals of each of the parties should be allowed free access and residence in each country, and provided for them the most most favored nation treatment. Nevertheless, Germany later established extremely onerous conditions on the entrance and residence of French citizens in Alsace-Lorraine. The action was supported on the ground of changed conditions-in this case the alleged anti-German plotting both in France and Alsace-Lorraine. These changes, it was argued, justified Germany in ignoring the treaty obligations as a measure of "self-preservation." The protests of France were of no avail, and obviously that nation was in no position to make a forceful demand for the observation of the treaty. ${ }^{19}$

Austria offers as a precedent the annexation of BosniaHerzegovania in 1908 despite her obligation under Article XXV of the Treaty of Berlin only to occupy the territory. The excuse given was the changed conditions then existing in the Balkan states, notably the fusion of Bulgaria and Eastern Rumelia. There was some protest by the other powers interested, excepting Germany and Russia, but when the latter accepted the change

\footnotetext{
${ }^{17}$ See Rolin-Jacquemyns, La question d'Orient en $5885-6$, I9 REV. DE DROIT INT. ET LtGis. CoMp., 37-49.

${ }^{13}$ KaUfMaNN, supra note 4 , at 13 , note 2.

${ }^{21}$ Rolin-Jacquemyns, La question des passeports en Alsace-Lorraine, 20 REv. DE DR. INT. ET LEGIS. COMIP., 6I5-623.
} 
the matter was dropped. ${ }^{20}$ It is to be noted that in this case the annexation made little difference in the European situation since Austria-Hungary was already by virtue of the Treaty of Berlin fully occupying and administering Bosnia-Herzegovania.

Again, in I9I 3 the clause was invoked by Servia in an attempt to have the treaty of IgI2 with Bulgaria revised on the ground that Bulgaria had changed the policy of the war then in progress from a defensive to an offensive one. It was also argued that Servia had lost her Adriatic Littoral while Bulgaria had acquired Thrace. These changes in the situation, it was said, were not within the contemplation of the parties at the time the treaty was signed. Servia, therefore, claimed the right to a revision of the treaty, or if that be refused, the right to unilaterally denounce the treaty was claimed. ${ }^{21}$

In our commercial treaty of I $\mathrm{I}_{5}$ with Great Britain, St. Helena was opened to us for commercial purposes, but upon Napoleon being confined there, Great Britain notified the United States that the island would again be closed, which policy was pursued until the death of Napoleon. This was a mere unilateral suspension of a treaty provision, since Great Britain eventually accorded to the United States all the privileges provided for in the treaty. It does not appear, however, that the United States admitted the right. of Great Britain even to suspend the treaty because of changed circumstances. ${ }^{22}$

The United States has not always allowed treaty obligations to stand in the way of supposed internal exigencies. During the World War, aliens were drafted into the United States army, despite treaty obligations with many nations not to do so. ${ }^{23}$ Some of the United States' legislation during the period of I882-I893 was considered by China to be contrary to the treaty obligations of the United States. ${ }^{24}$ Perhaps the most in-

${ }^{20}$ Kaufmann, supra note 4 , at 3 I et seq. The political aspects of the case are examined in G. Lowes DickINSON, THE INTERNATIONAL ANARCHY, I904-I9I4 (1926) I55-I85. 442.

${ }^{21}$ Crandali, Treaties, Their Making and Enforcearent (2d ed. Igi6)

22 Foster, Practice of Diplomacy (1906) 298-309.

${ }^{23}$ See (rgi8) 28 YaLF L. J. 83, note.

${ }^{24}$ IV Moore, Digest of Internatronal Law (xg06) $\$ \$ 567-568$. 
teresting case, however, concerns the demand made in I88I upon Great Britain for a revision of the Clayton-Bulwer treaty. ${ }^{25}$ It was pointed out that the United States had grown enormously during the thirty-eight years the treaty had been in force, and that the expansion of the nation made a continuance of the treaty incompatible with the national interest and safety under the new circumstances. It was said that

“. . . this government, with respect to European States, will not consent to perpetuate any treaty that impeaches our rightful, long-established claim to priority on the American continent"

and further that

“. . . the government of the United States would feel it had been unfaithful to its duty and neglectful towards its own citizens if it permitted itself to be bound by a treaty which gave the same right through the canal to a warship bent on destruction that is reserved to its own navy sailing for the defense of our coast and the protection of the lives of our people." 26

As is well known, the discussion ended amicably in the HayPauncefote Treaty of Igor.

The agreement of 1818 between the United States and Great Britain relative to armaments on the Great Lakes was violated by both parties as changing conditions seemed to them to demand it. Here again we find "changed conditions" being combined with "national safety" and "interest" as an excuse for treaty breach. It is further noteworthy that in each instance the act contravening the treaty stipulation met with protest from the other party. ${ }^{27}$

The recent legislation in Mexico giving effect to Article 27 of the Mexican Constitution of I9I7 is in conflict with Mexico's treaty obligations towards several countries. This failure to observe treaty obligations has also been defended by invoking

\footnotetext{
${ }^{25}$ III Ibid., 130-254.

${ }^{2} \mathrm{Mr}$. Blaine to Mr. Lowell, Foreign Ret.attons (I88I) 555.

${ }^{27}$ I MOORE, stipra note 24, I 43.
} 
the rebus sic stantibus clause as implicit in all Mexico's treaties. ${ }^{28}$

Articles $3^{\mathrm{I}}$ and 435 of the Treaty of Versailles, denouncing respectively the treaty of 1839 neutralizing Belgium, and that of I8I5 providing for neutral zones in Savoy, are said to be examples of the operation of the clause. The articles of the treaty do mention changed conditions, but it is to be remembered that the nullification of the old treaties was by means of a new one, no implied clause in the old treaties being necessary for such a procedure.

Several recent unilateral denunciations of treaties have taken place which would perhaps be excused if the rebus sic stantibus be admitted as having a recognized place in international law. Persia in I9I8 declared that the treaties establishing spheres of influence there (particularly the Anglo-Russian treaty of 1907) were null and void. ${ }^{29}$ In Igrg China announced that she would no longer be bound by the treaties of 1913 and I9I5 with Russia and Mongolia, it being said that the Mongolian autonomy created by the treaties no longer corresponded to the latter's wishes. An unsuccessful protest was made by Russia. ${ }^{30}$

Norway, claiming that the establishment of the League of Nations together with the other changes of the European situation since the war made the treaty of 1907, guaranteeing the territorial integrity of Norway and requiring that nation not to alienate any portions of its domain, no longer binding, unilaterally denounced it on January $8,1924^{31}$ With the exception of Russia, the other signatory powers notified Norway that in the future they had no intention of requiring the fulfillment of the treaty. There was no indication, however, that the unilateral abrogation of the treaty was accepted. On the contrary, the statements of the notes that the respective governments would

\footnotetext{
${ }^{23}$ MacGregor, ¿ La fracción I del Articulo 27 de la Constitución viola los tratados celebrados por México con algunas naciones extranjeras?, I REVISTA MEX. DE DER. INT., 568-593.

"Fauchille, Traité de Droit International Public (8e. éd.) Tome I, Partie 3, 386.

* (r920) 27 Rev. GÉn. de Droit Int. Pub. 106.

2 (I924) 31 ibid., 299.
} 
not in the future force their rights under the treaty indicate that they did not consider Norway's announcement as putting an end to it. Here again is a simple case of a treaty being abrogated by the fiat of one nation because the other signatory powers had no sufficient interest in its continuation.

Treaties involving extraterritoriality have sometimes been the subject of debate on the matter of their abrogation by the subjected country alone. ${ }^{32}$ In the case of Japan, the extraterritorial privileges were removed by mutual consent, and the cessation of the capitulations in Turkey was recognized by the Treaty of Lausanne, though Turkey had long previously claimed their end. The failure of the. United States to ratify the Treaty of Lausanne places the United States in a somewhat anomalous position, since that nation has not yet recognized that its extraterritorial privileges there are at an end. The question might easily arise in this case as to whether or not Turkey would still be bound to accord those privileges to the United States.

The present difficulties in China have occasioned large concessions on the part of Great Britain, perhaps in anticipation of a unilateral declaration by China that the existing extraterritoriality treaties were no longer binding upon her because of changed conditions. These treaties of extraterritoriality are somewhat similar in character to those establishing international servitudes, and the several servitudes that were established by the treaties that followed the late European war; such as the Kiel Canal, may perhaps at some future time be the cause of an invocation of the clause.

Treaties of peace raise another interesting question of international law which may with propriety be discussed in conjuncton with the rebus sic stantibus clause. It is now universally conceded that the doctrine of duress has no application as between states. The doctrine is recognized, however, with respect to the agents of the state appointed to conclude a treaty. ${ }^{33}$

Perhaps the theory of the equality of states may have influ-

\footnotetext{
${ }^{2} e . g .$, Travers Twiss and Paternostro on extraterritoriality in Japan. 23 REV. DE DR. INT. ET LEG. COMP. I-29; 176-200, and 25 ibid., 2I3-2I9.

${ }^{2} F_{\text {AUCHILLE, supra note 29, Tome I, Partie 3, } 298 .}$
} 
enced the acceptance of the rule that duress practiced by one nation upon another will not be recognized as such in international law. States being equal, one cannot logically impose upon another. This idea is so obviously false as to merit little attention. ${ }^{34}$

It is usually said that if the doctrine of duress were admitted in international relations, dire consequences would follow. The conqueror would refuse an honorable peace and proceed to the annihilation of his enemy, for otherwise there could be no certainty in the future relations of the belligerents. Stripped to the bone, the argument is simply that once the doctrine of duress be admitted there can be no stability in international relations.

The argument seems powerful, but an examination of it in the light of experience somewhat lessens its force. The first answer that comes to mind is that no particular stability is apparent under the present system, despite the claims that it tends to preserve the status quo. Alsace-Lorraine has not yet ceased to be a mere pawn upon the European checkerboard, and on our own continent the case of Tacna-Arica lends little support to the belief that refusing to allow the revision of a treaty of peace makes for stability.

Two or three hundred years ago, perhaps, the argument might have had some validity. Ceding. far off, thinly populated colonial territories, the value of which was not often fully realized, was apt to leave no such desire for revenge and the recovery of the territory as do territorial cessions at the present time. The extreme value of colonial possessions is now universally recognized, and to part with them, or to cede territories thickly populated with one's own people, such as Alsace-Lorraine or Tacna-Arica, creates a continuing source of propaganda for war parties, and tends more to disturb international relations than to quiet them. It is quite simple to convince a nation's people of the holiness of a war waged for the rescue of fellow nationals thrown by a treaty into the jurisdiction of the former enemy.

$\boldsymbol{M}$ For a detailed examination of the theory of the equality of states see Edwin D. Dickinson, The Equality of States in INTERNational LaW (I920). 
In our times, as is eloquently attested by the Treaty of Versailles, the economic misunderstandings of treaty draftsmen ${ }^{35}$ may well create a situation by which the whole world becomes affected, and not merely the ex-belligerents as was the case under an international system less highly integrated. The economic repercussions of a faulty treaty of peace may work such havoc internationally that it may fairly be said that the whole world has a legitimate interest in the revision of such improperly drawn treaties.

Dangerous international situations also arise from treaties of peace based largely on mistakes of fact imposed upon the conquered party. Such a situation has arisen from Article $23 \mathrm{I}$ of the Treaty of Versailles, wherein Germany unqualifiedly "accepts" responsibility for the war of I9I4-I9I8. It now appears that such an assertion is probably contrary to the facts, ${ }^{36}$ yet the large portions of the treaty directly based upon it continue to be accepted by the victors as valid and not susceptible of revision. The need of revision of Article 23I and the articles based upon it must be apparent to those who have inquired into the international situation created by them, yet no method is seen to bring about such a revision unless the conquerors become convinced of the unwisdom of perpetuating a probable untruth.

So with the treaties imposing unusual international disadvantages upon nations, such as the unequal treaties with China. These treaties cannot be regarded as having been freely entered into by both parties, and a potentially evil international situation arises from them which invariably ends in a clash. The collision may result in a readjustment without the intervention of arms, such as was the case with Japan, or it may lead to a display of force such as is now to be seen in China.

It is difficult to conceive of an unjust treaty imposed upon a conquered nation, or one too weak to resist the demands of a more powerful state, which does not offer great incentive for a

\footnotetext{
${ }^{3 s}$ See particularly Keynes, The Economic Consequences of the PeAce (1920), and the companion volume, A REvision of THE TREATY (I922).

${ }^{26}$ Consult Barnes, The Genesis of the WorLd WAR (2d ed. I927), and G. Lowes DiCKINSON, The INTERNational ANaRCHy, I904-I9I4, supra note 20.
} 
future breach of peace. To argue that these treaties may not be revised by applying internationally the doctrine of duress because such a possibility would prevent stabilization assumes that the present system prevents the evils which are attributed to that doctrine. It takes no long reading of history to perceive that whatever stability may be claimed by the present system is at best but temporary . . . a sort of breathing space for the losing party to gather strength for the attempt to recoup his losses. It is not easy to see how a recognized application of the duress doctrine to proper cases would make matters any worse. It is submitted that, in fact, it would probably improve international relations. It is not suggested that the subjected nation unilaterally declare itself released from obligations imposed by violence. As in municipal law, a court would be required to examine the facts of each case and pronounce judgment upon the existence or absence of legal duress. The fact of duress could scarcely be denied in the case of many treaties . . . the real question is the advisibility of the fact being admitted by international law as the basis for a legal modification of such a treaty. Instead of attempting to bring about the desired change by force of arms, as is now the only possible way, the method of judicial decision would be substituted.

It might be argued that the judicial decision would no more definitely decide the question than would a decision by arms. Perhaps there is some force in the argument, but even assuming its general validity, an amelioration is believed possible by the judicial method. We may take the classic example of AlsaceLorraine as an illustration. Originally German, it has been passed back and forth between Germany and France until racially and culturally each nation is able to make a strong case for its equities in the territory. This is so because after each war the defeated nation has required so long a time to regain sufficient force to warrant an attempt to regain the lost territory that the conquering state has had ample time to plant and nurture its own people, culture and language among the original inhabitants. With the territory thus divided in its inhabitants, both nations continue always to have a vital interest in it. The present system, 
therefore, allows the creation of an artificial national interest where there was none before and where none would have been in the normal course of events. Every new "national interest" means a new possibility for war. If, for instance, France is successful in imposing a sufficient amount of her culture and people in the Saar basin before the period arrives for that territory to choose between France and Germany, we shall have created another Alsace-Lorraine, which would be far from helpful to the highly artificial relations already existing in Europe.

The intervention of a court for the decision of these questions would make possible an equitable restitution before an artificial, yet continually growing, national interest could be impressed on the disputed territory by the victorious nation. It would be easier for France to forget the loss of territory containing only Germans than a territory comprised in half by her own people. Obviously the mere decision of a court would not dispel the feelings which attach to the old strips of territory which have been handed back and forth, but it would make it possible to prevent new ones from being created:

These suggestions are not offered with the idea that they will immediately operate to improve international relations. It must be admitted that there is little chance that the major nations would be willing at this time to accept them. The growth of international law is gradual but none the less certain. It is believed worth while, however, to re-examine such ancient theories or principles as seem to encourage rather than discourage international strife in the hope that discussion will be aroused which may in the future attain such volume as to force the gradual acceptance of legal theories more compatible with observed phenomena, and more conducive to the pacific relations of states.

It seems strange indeed, that writers on international law should adopt a defunct principle of the civil law ${ }^{37}$ allowing states to escape obligations freely entered into, yet refuse to recognize any theory which would permit the revision of treaties

${ }^{s T}$ Lammasch, writing in II STRUPP, WÖRTERBUCH DES VÖLKERRECHTS, loc. cit. supra note I, remarks that while the theory was dying in the civil law, international law theorists took it up and attempted to perpetuate it. 
forcibly imposed and often notoriously inequitable. While admitting that the two types of treaties should be governed by different considerations, it would seem more conducive to the ends of justice that the present system adopted by the writers be reversed.

Returning now to the type of treaty freely entered into, we note that the kinship of the implied clause rebus sic stantibus and the so-called right of self-preservation is evident not only in the words of the theorists, but in the reasons assigned by states attempting to escape liability under a treaty because of "changed circumstances." The various theories advanced are all the result of $a$ priori reasoning, the conclusions being based, as a matter of fact, upon preconceived notions of political theory or analogies culled from private law. Should we admit that treaties are concluded with the tacit understanding written into them that rebus sic stantibus, we still have to solve what constitutes the rebus mutatis. Here, in effect, is the danger and the fallacy of the idea, for it leaves to each party to determine when a rebus mutatis has occurred. Some writers maintain that a legitimate escape by way of the clause may be had only after invitation to the other party or parties to confer upon the matter and a failure of the conference. ${ }^{38}$ Just how such a procedure would solve the difficulty is not shown, for once the clatise be admitted to a place in international law the recalcitrant nation is not apt to modify its demands to any great extent because of the objections of the other party. Such a procedure would no doubt be more courteous than a simple unilateral declaration, but, it is submitted, offers little in the way of a practical solution of the problem involved. In view of the language of the United States in the case of the Clayton-Bulwer Treaty it is not to be supposed that the United States could have been induced by Great Britain greatly to modify the assertion that the old treaty could not stand. England, it is submitted, agreed to a revision of the treaty, not because of a recognition that the treaty contained a tacit clause of rebus sic stantibus, but because it was the politic

\footnotetext{
${ }^{33}$ Rolin-Jacquemyns in 20 REv. DE DR. INT. ET LEG. CoMp. 623.
} 
thing to do under the circumstances, and because a refusal on her part to negotiate a new treaty satisfactory to the United States would probably have resulted in the loss of even those advantages which were retained by England under the HayPauncefote arrangements.

Austria-Hungary was allowed to annex Bosnia-Herzegovania with impunity, not because there was a tacit clause of rebus sic stantibus in the Treaty of Berlin, but because Russia and Germany, for political reasons of their own, refused to join the other powers in a protest. ${ }^{39}$ Likewise, Russia was in a favorable position to force her demands on the other powers after the circular letter attempting to unilaterally abrogate the provisions of the Treaty of Paris relative to the Black Sea. The protocol signed by the parties was, moreover, a categorical denial of both the clause rebus sic stantibus and the idea that Russia was legally disengaged from the obligations of the old treaty until after the act of the London Conference.

The same type of observation might be made as to the other alleged precedents for the existence of such a clause in international law. In fact, no case is known to the writer in which a nation has been able to escape treaty obligations because the other party recognized the clause rebus sic stantibus as implied in the treaty by international law. Rules of international law do not grow from mere unilateral declarations of nations, no matter how long practiced, when those declarations are uniformly denied by other states. The opinions of the writers, even though they be unanimous, cannot effectully create a rule of law when the supposed rule is uniformly denied in practice. So far as is known, the clause has never been considered by an arbitral tribunal or other international court, though there is dictum in the case of Russia $v$. Turkey to the effect that intervening force majeure would be a good plea to a suit upon a treaty obligation. ${ }^{40}$

${ }^{29}$ G. Lowes Dickinson, supra note 20, I68-I8I.

"Scort, The Hague Courr Reports 3I5. Kaufmann, stepra note 4, at 58, states that the Supreme Court of Switzerland has recognized the principle. The United States Court of Claims recognized it in some dicta in the French Spoliation cases, citing Woolsey and the Clayton-Bulwer Treaty case. Hooper v. United States, 22 Ct. Cl. 408, 416 (1887). 
Since the recognition in international law of such an implied clause is at least highly questionable, it is well to examine the claims for its necessity or desirability. It has been said that no nation can intend to bind itself in perpetuity, and that such an idea is incompatible with state sovereignty, and the very nature of the state. ${ }^{41}$ An analogy is found in the private law of contracts which refuses to give effect to contracts of service for life, and the argument that the state is incapable of alienating certain of its functions may find some analogy in the implied constitutional limitations on the alienation of the public domain. ${ }^{42}$ Analogies drawn from private law in support of international law theory, while often useful, are by no means controlling or necessarily desirable. What is useful and possible in private law is not always so in international law. Were we, for example, to accept the first analogy, treaties providing for international services in perpetuity would be voidable immediately at the will of the obligor. What then, for instance, would become of the obligations assumed in the Danish sound which Denmark undertook for a money consideration paid by the other powers who denied Danish proprietary claims in those waters. ${ }^{43}$ May Germany repudiate her Kiel Canal obligations at any time because she could not bind herself to furnish services perpetually? May Panama at any time repudiate the obligations she undertook with respect to the Panama Canal because she could not legally assume those obligations? What value would there by in concluding the proposed treaty with France outlawing war between the two nations if it be impossible for a state to perpetually bind itself? It is submitted that nations can and do obligate themselves without limit of time, and that to read into international law an outworn rule of private law, would necessitate such a large number of exceptions as to reduce the rule to a mere series of words.

The second analogy, to the effect that nations may not alienate certain attributes-usually designated by the writers as

- DE LOUTER, supra note I3, at 5 IO.

${ }^{4} C f$. Illinois Central Ry. v. Illinois, 146 U. S. 387 (1892). But see DaNA, WhEATON's INTERNATIONAL LAw 50.

4I MOORE, supra note 24,659 et seq. 
"sovereignty" or things held in "trust" for the people of the state -is also of such vagueness as to make it practically unworkable. The element of unilateral determination of treaty rights and duties still remains, for the constitutional laws of the various countries are by no means uniform as to what may or may not be alienated by the legislature, and it is thus probable that each nation would search its own'municipal law for analogy and would demand that its own concept be accepted. Under such rules the treaties now in force between the United States and several of the Central American states would be terminable at the will of any of them, inasmuch as the treaties provide for a certain derogation of their sovereignty. It is is believed that many of the writers who assert such a doctrine had in mind the ancient practice of secret treaties upon which the public was held in ignorance. This, of course, would not include those writers of the German Polizeistaat school. It was probably thought inequitable that some monarch, in pursuit of his own political scheming, should alienate the public domain, or perpetually bind his people by an onerous treaty. With this idea was combined the changing ideas of the nature of the state and sovereign responsibility. It is not here maintained that the day of secret treaties is past, despite the pious assertions of League diplomats, but it is unquestionable that under the present system of parliamentary ratification of treaties it would be difficult to make the old reasoning support the doctrine. Witness the action of the Swiss public not so many years ago when a railway treaty was negotiated with Germany and Italy giving the latter nations rights unlimited in time over Swiss territory which the Swiss public thought to be detrimental to the public interest. ${ }^{44}$ So much for the private law analogies offered. They are, of course, not technically concerned with the clause rebus sic stantibus, but have been offered as evidence that there must be some sort of limita-

\footnotetext{
"Scelle, 20 Rev. GÉn. DE Dr. INT. PUB. 484-505, particularly pages 499-500, where he maintains the theory that the clause operates when the end sought by the parties is no longer obtainable through the treaty, and defends the right of either nation to decide for itself when the treaty ceases to contribute to that end, even in the face of armed conflict. $C f$. Prader-Fodéré, op. cit. stupra note 5 , at 928 .
} 
tion implied in treaties to prevent them from being permanently effective.

Let us suppose for a moment that international law actually does read the clause into treaties. What will be the practical effect of it? Taken literally, any appreciable change of the political or economic conditions existing at the time the treaty was signed would entail its extinction if either of the parties desired it. But if we are to believe the writers, the clause doesn't mean that. Only certain types of changes, it seems, would justify a nation in claiming release from treaty obligations by means of the clause. Thus if the treaty becomes incompatible with the constitutional and private law growth of the nation, conditions have "changed" sufficiently for a legitimate invocation of the clause. ${ }^{45}$ Or, if the circumstances become so changed that the observance of the treaty would be inconsistent with the so-called right of "self-preservation," the clause would come into play and relieve the sufferer. ${ }^{48}$ Thus an ambiguous clause is defined in even more shadowy and disputable phrases. The danger of sanctioning such an indefinite and indefinable clause in the absence of courts charged with delimiting its meaning must be recognized.

The above definitions of rebus mutatis have called forth both exceptions and denials. To some the changes interfering with internal legal or economic growth do not constitute a true rebus mutatis-the change must be such as to cause the treaty to become a veritable threat at the very existence of the state, ${ }^{468}$ while others would merely distinguish between those internal institutions which represent an expression of the droit nécessaire (i. e., the state's idea of a proper political theory), and mere administrative changes. ${ }^{46 \mathrm{~b}}$ Still others assert that it may be in-

\footnotetext{
${ }^{45}$ HefFter, Droit International (4e éd.) 221; Olivi, D'un Cas Controversé de Cessation de la Force Obligatoire des Traités Internationaux, $23 \mathrm{REV}$. $\mathrm{DE} \mathrm{DR}$. INT. EI LEG. COMP., 590-609.

${ }^{46}$ Hald, INTERnational LAw (7th ed. I9I7) 36I-370, esp. 369. Note that Hall severally criticizes Heffter, Hautefeuille, Bluntschli and Fiore for their "high sounding generalities," and then offers as a yardstick the "right of selfpreservation" of states, a right which has exactly the meaning that each state desires to give it.

16z Despagnet-DeBoeck, Droit International Public (4e éd.) 707-7io. Rolin-Jacquemyns in 20 REV. DE DR., ETC., 615-623.

tob Olivi, in 23 REV. DE DR., ETC., 590-609.
} 
voked only when the "highest interests" of the state are at stake. 47. Most of the writers admit that the recognition of the clause is dangerous, but would not on that account do away with it entirely. It has been said that if the treaty were "loyally" discussed by both parties, the result would be a conciliation of the opposite extremes of the doctrine and the assignment of reasonable limits to the treaty. ${ }^{48}$ It has also been assumed that circumstances of such a character as would justify the invocation of the clause would be such that the benefited party would readily acquiesce in the obligor's demands. ${ }^{49}$ To the first statement it may be answered that an amicable agreement may be reached through a conference of the parties because the nation demanding release still retains a considerable bargaining power, or because the benefited party find it politic to agree to a revision. The second statement assumes that the clause will be invoked only in "proper" cases, those cases being such as would appeal to the sense of justice of any state. In view of past practice the assumption would seem rather too sanguine. In either case, however, the necessity of the clause rebus sic stantibus is not apparent. If the obligor is able to bargain himself out of a bad position, or if the obligee for political or even equitable motives agrees to release the obligor from his excessive burden, it is difficult to see just what the disputed clause has to do with it. It does not appear that the results would be any different if the clause had never been heard of. ${ }^{50}$ The writer is unacquainted with any case where a treaty has been revised as a matter of legal right.

"Schmmt, Utber die Völkerrechtliche Clausula Rebus Sic Stantibus (Leipzig, 1907) 25. Schmidt, however, denies any legal validity to the clause.

" Cavaglieri, La Funzione della Clausola Rebus Sic Stantibus nei Trattati Internazionali, jI ARCHIVIo GruRmICo, IO6-I40.

- Crandall, op. cit. supra note $2 \mathrm{I}$, at 44I.

- For example, it is not uncommon for the legislature of a state to pass laws contravening treaty obligations, thus forcing the governmental agency charged with foreign relations either to nullify the legislation, if possible, or to negotiate new treaties. This was done by the United States when the Lafollette Seamen's Acts made it impossible for the executive to comply with the treaties requiring the United States to return all deserting seamen to their ships. The nation whose rights under the treaty are injured may demand some other compensatory privilege as a price for agreeing to a new treaty, or the new treaty may be agreed to as a matter of comity. 
Two formidable objections to the clause have never been adequately refuted, and it is believed that no such refutation can be made. First, the usual treaty is now concluded for a certain term of years, with some type of "option" clause attached for renewal or denouncement. The parties to such treaties (usually commercial treaties) customarily take into consideration possible economic or political changes in the future, and limit the obligatory term to such a period as they deem safe for their individual interests. It is difficult to conceive of any eventuality short of war, which, under such a treaty, would even equitably entitle the obligor to relief. ${ }^{51}$ The treaty is made for a specified space of time for the very purpose of permitting periodic adjustments to meet changed circumstances unforeseen by the parties.

The second objection is that nations entering into treaties are not unaware of the disputed clause, and there would be little objection to the actual insertion of it into the treaty if the parties intended to contract in that fashion. Nevertheless, it is highly improbable that any nation would be willing to sign a treaty with the bare clause included, since it would be fatal to the very purpose of the usual treaty-to provide a binding and dependable delimitation of the rights and duties of the parties with respect to a certain thing, or for the accomplishment of a certain objective. To find by implication that the parties must have understood such a clause to be part of the contract therefore does considerable violence to ordinary credence.

Furthermore, in actual practice, the theories heretofore advanced would tend to make pacta sunt servanda the exception rather than the rule. The nation desiring to be freed of the burdensome treaty might either attempt to do so by simple declaration, or might request a conference with the other party for a revision of the treaty. In either case the obligee would be

${ }^{31}$ The Norway case (supra note $3 I$ ) can scarcely be defended upon any grounds of necessity. The treaty in question ran only for ten-year periods, and was susceptible of denouncement by notice two years before the end of any period. By waiting two years Norway could have denounced the treaty conformably with its terms. It does not appear that the two-year wait would have worked any injury whatever upon Norway. The case is but a sample of the useless illegality made possible by the acceptance of the rebus sic stantibus clause. 
placed in the position of having to convince the obligor of his erroneous assumptions. That is to say, the existence of a legal unilateral means of escape from an onerous treaty obligation would tend to encourage nations in seeking that escape, and a certain air of righteousness might be lent to their actions. An opportunity would be afforded for the breach of a treaty without acknowledging it. This would be true, of course, only so long as nations refuse to admit the possibility of judicial determination of questions said to involve the national "honor" 52 or "safety", and that such judicial determination may come after an automatic submission of the disputed question to an international court.

As has been noted above, the more noted cases involving the clause in Europe have been concerned with treaties involving the so-called balance of power. The existence of such a system may have had a great deal to do with the development of the notion that treaties were to be understood rebus sic stantibus. ${ }^{53}$ Neutrality treaties have in Europe been solely for the purpose of preserving the "équilibre," so that the clause might well serve to excuse Germany's failure to observe the treaty of 1839 neutralizing Belgium. The later close union of Russia and France with the subsequent co-operation of Great Britain left Germany with potential enemies on both the east and west frontiers. A strong argument could be made that this change in the grouping of the European powers was such a change as to make the treaty no longer binding under the rebus sic stantibus theory. ${ }^{54}$

\footnotetext{
"See Perla, What is Natronal Honor? (igrg).

${ }^{\infty}$ Cf. Russia's report to the First Peace Conference at the Hague, where it was said:

". . the mutual rights and duties of states are determined by the totality of what we call political treaties, which are nothing but the temporary expression of chance and transitory relationship between the various national forces. The treaties restrict the parties so long as the political conditions under which they were produced remain unchanged. Upon a change in these conditions the rights and obligations following from these treaties necessarily change also";

in Scott, Reports to the Hague Conferences (19i7) 97.

The Treaty of Versailles, by Article $3 r$, ended the neutrality of Belgium, it being said that it was no longer compatible with changed conditions. The difference between this treaty nullification and that of Germany is not so much one of force of reason, but of method. The one was tunilateral and illegal, the other by a new treaty-a legal method.
} 
It is submitted that the clause rebus sic stantibus as sustained by the majority of writers is so pregnant with danger as to outweigh any considerations of possible benefit which might be derived from it in exceptional cases. We may even recognize the possibility of cases arising where the obligor should be released from his obligation without thereby sanctioning the clause. Is there no other way by which these exceptional cases may be settled without seriously undermining the sanctity of treaty obligations? Article I9 of the Pact of the League of Nations recognizes that treaties may be in need of revision, and provides that in such cases the matter shall be handled by the Assembly, which is, of course, the poorest means at the disposal of the League for such a purpose. The one attempt that has been made to bring Article 19 into play has met with failure and demonstrated the hopelessness of the Assembly as a means for the revision of faulty treaties. ${ }^{55}$ Article 6 of Project No. 2I of the American Institute of International Law, ${ }^{58}$ however, provides no means of putting an end to a treaty other than a fulfillment of the obligation; the expiration of the agreed time; the disappearance of one of the parties, subject to the rights of succession; or by renunciation on the part of the nation in whose favor the obligation was created. Little assistance is therefore to be found from these sources.

Some assistance may be found in the war-time development of the English doctrine of "frustration" in contracts, in which a tendency is shown towards recognizing economic impossibility as well as absolute impossibility as a reason for the court to grant a rescission of the contract. ${ }^{57}$ This is quite similar to the

Bolivia attempted to bring the treaty of Ig04 with Chile before the Assembly, but upon an unfavorable committee report, the demand was withdrawn. The consensus of opinion seems to be that no treaty may be considered without the unanimous consent of the Assembly. Obviously the nation not wishing to revise a treaty can always effectively block the efforts of the other party to that end. The matter is studied in detail by GoErzNER, LA REVISION DES Traites Sous le Regrme de la Soctete des Nations (Paris, 1925).

6 (Ig26) 20 American Journal of International Law, Special Supplement, 349.

${ }^{67}$ See, for example, Metropolitan Water Board v. Dick Kerr \& Co., [IgI8] A. C. II9, where a contract was held to be completely inoperative because of extraordinary changes which involved a practical economic impossibility of per- 
continental doctrine of force majeure, and as has been noted above, we are provided with at least a dictum of the Hague Tribunal that the doctrine of force majeure is recognized by international law. The meaning and extent of the doctrines of force majeure and frustration are reasonably clear, and are not susceptible of being interpreted in any such free manner as the clause rebus sic stantibus. ${ }^{58}$ Further, the demanding party would not by these doctrines be placed in the advantageous position made possible by the rebus sic stantibus theory, since there could be no widely diverging views as to the meaning of the doctrines. But even though the theories above mentioned would furnish a reasonably clear and stable measure for the determination of liability under a treaty, we must still recognize that the intervention of an international court is recessary for a judicial determination of the rights of the parties. Unfortunately nations are still unwilling to submit to such courts matters pertaining to the national "honor" and "safety," though as a matter of fact the "honor" spoken of is often translatable into terms of dollars or pounds sterling. It is probable, therefore, that until education in international matters has reached the stage where the idea of a state being called to the bar of justice is no longer shocking to national sensibilities, a judicial determination ad hoc of whether or not a treaty continues to be binding on the parties is not within the realm of probability. Unless the possibility and method of revising a treaty be specifically decided beforehand, any demand made for its later revision will necessarily be founded on the national honor and safety.

The matter is not hopeless, however, and there is still one solution for treaties to be made in the future which seems to be

formance, even though the contract provided for mere suspension in case of such a contingency. For a brief comparison of the English and American practice, see Conlen, The Doctrine of Fristration as Applied to Contracts, (I92I) $70 \mathrm{U}$. OF PA. L. REv. 87 .

${ }^{5}$ If the demanding party is able to support his demand for a rescission of the treaty with the doctrine of rebus sic stantibus, which is necessarily a vague concept, the obligee is placed in the position of having to rebargain in the attempt to save whatever advantages he can from the old treaty or lose all of them with the alternative possibility of further loss through reprisals or war. If, however, the demanding party is able to produce no such accepted doctrine, that party actually has the burden of showing bona fides and a sound case in fact. 
within the realm of the possible. Under the present system, any sort of implied clause or condition in treaties imports a danger not present under like circumstances in municipal law. Unilateral determination of treaty obligations makes possible, and even probable, either economic or armed warfare, either of which would be of far more serious consequences than the observation of the onerous treaty provision would have been. It is therefore imperative for the peaceful development of nations that the rigor of the rule pacta sunt servanda be retained. The remedy of implying the clause rebus sic stantibus is worse than what little evil might result from a rigid observation of the rule. It would, however, in no way impair the force of the rule if the parties, at the time of making the treaty, were to insert a clause providing that intervening force majeure or frustration would entitle either party to a revision or revocation of the treaty, and that in case of dispute the matter be settled by some international judicial body. It is submitted that nations might be willing to accept such a clause in treaties, since there is very little difference of opinion as to what constitutes a force majeure or frustration, so that they could contract with a considerable assurance of knowing what the contract meant. Such a clause would also refute a later claim to the existence of an implied clause of wider scope. It would forestall the invocations of national "honor" and "safety" so often heard, and which almost invariably prevent a judicial determination of the question. ${ }^{59}$ If the matter be entirely settled beforehand, no opportunity is left for justiciable issues to ripen into political questions. Thus one type of troublous question would be taken out of the category called "political" and added to that described as "legal." 60 Every question taken from the former category and placed in the latter

\footnotetext{
${ }^{5}$ No real objection on the part of a nation is perceived to the submission of a question of force majeure or frustration to a court, if the matter were agreed on beforehand. Such an agreement at the time of making the treaty would raise no questions of national honor, and if a question later arose, the automatic submission to a court would forestall the dispute which usually results in a refusal to arbitrate because the nation's "honor" has then become involved.

${ }^{\infty}$ See the analysis of Borchard, The Distinction Between Legal and Political Questions (ig24), reprinted from the Proceedings of the ArIeriCaN SOCIETy OF InTERnational LaW (April 24-26, I924).
} 
is an added step towards the establishment of law as the final means of settling disputes between states.

The procedure suggested would require nations in treaty matters to stand squarely on the basis of law or outlawry-the equivocal and self-righteous position made possible by the theory of the clause rebus sic stantibus would no longer be open to them. 